\title{
SUS304 およびS45Cの初期凝固における粒選択挙動
}

\author{
黒田 悠加* ·江阪 久雄 $* 2 \cdot$ 篠塚 計*2 - 田村 学*2 \\ Grain Selection during Initial Solidification for SUS304 and S45C \\ Yuka Kuroda, Hisao EsaKa, Kei ShinozuKa and Manabu TAmURA
}

Synopsis : In order to understand the initial solidification of the continuous casting process, the drop tests have been performed using SUS304 and $\mathrm{S} 45 \mathrm{C}$. The grain is defined as the group of dendrites that grow in the same direction. The grain size of SUS304 quickly increases from surface as solidification proceeds. On the other hand, the grain size of $\mathrm{S} 45 \mathrm{C}$ remains constant in the range of experiment. This is due to the difference in the distribution of the growth direction of dendrites. The grain selection model has been modified by taking the distribution of growth direction into consideration. Then the change in number of grains with distance can be explained quantitatively. In order to clarify the difference in the growth direction of dendrites, the influence of the superheat has been evaluated. It has been found that the dendrites incline heavily and radially with increasing the superheat. This may be due to the melting of heterogeneous nuclei and enlarging the high-undercooling region near the chill plate.

Key words : initial solidification; nucleation; dendrites; grain selection; modeling.

\section{1. 緒言}

鋳片表面での凝固，すなわち初期凝固は内部組織の開始 点であり，鋳片の表面品質は表面近傍で形成される凝固組 織に支配されることから, 表面での凝固現象は非常に重要 である。よって, 表面欠樎の発生を抑え, 表面品質を向上 させるためには, 表面近傍で形成される初期凝固現象の理 解が必要である。

初期凝固に関しては古くから多くの研究者が様々な合金 系, 手法を用いて研究している。例えば, Bower and Flemingsは $\mathrm{Al}-\mathrm{Cu}$ 合金の鋳塊をX線回折により詳細に分析し， チル板表面における結晶がランダムな方向に分布している ことを明らかにしている1。Biloniらは同じく Al-Cu合金 を用い，鋳塊表面にディスクとプリデンドライトが現れる ことを明らかにし，それはチル板表面で大きく過冷し，核 生成したものであると述べている ${ }^{2,3)}$ 。また，西らはディ スクを中心にチル晶が成長していることを明らかにしてい

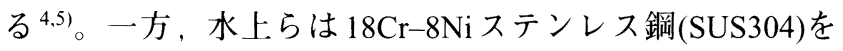
用いた初期凝固の詳細な研究を行い, 初期凝固時の冷却速 度と過冷度, 結晶粒径の関係を明らかにしている ${ }^{6-9) 。 し ~}$ かし，鋼の連続鋳造においてはBiloni らの実験での $\mathrm{Al}-\mathrm{Cu}$ 合金のように大きく過冷を得ることはなく，また鋳片表面 でディスク，プリデンドライト等が見られたとの報告例は ない。また, 水上らの実験は, 試料の質量が $3 \mathrm{~g}$ と少量の ため, 現行のスラブ連鋳などと比較すると冷却速度は 1 桁
以上大きい。このように, 鋼の連続鋳造に近い条件での鋼 の初期凝固の定量的検討はほとんどされていないのが実情 である。

そこで本実験において，汎用鋼であるSUS304とS45C を滴下実験し，連続鋳造とほぼ同等の冷却条件において， チル晶から柱状晶にかけての粒の形成過程について詳細に 検討を行った。

\section{2. 実験方法}

\section{$2 \cdot 1$ 鋳造方法}

滴下実験の装置の概要を Fig. 1に示す。エアーシリン ダーによる上下可動式となっており，上部で高周波誘導加 熱を行い，下部で滴下を行った。小孔のあいた石英管内に あらかじめアルコール洗浄した約 $20 \mathrm{~g}$ の鋼を入れ，アルゴ ン䨌囲気中で高周波誘導加熱により加熱, 溶解した。温度 の均一化のため所定の温度で $10 \mathrm{~s}$ 保持後, 石英管をチル板 直上まで降下させ，石英管内の圧力を上げることにより， 溶鋼をチル板上に滴下させた。チル板はSS400の鋼板を用 い，滴下時の鋳型温度は室温とした。なお，チル板の表面 状態を一定にするため, \#800耐水研磨紙で研磨した後, アルコール洗浄を行った。溶鋼を石英管から滴下する際, 落下の衝撃を緩和するため, 耐火物で作成した漏斗を緩衝 材とした。溶鋼温度の測温は側面に設置したファイバ型赤 外線放射温度計により行った。試料内部の温度は鋳型上に

平成 17 年11月15日受付 平成 18 年3月7日受理 (Received on Nov. 15, 2005; Accepted on Mar. 7, 2006)

* 防衛大学校理 工学研究科前期課程学生 (Graduate Student, Nationaal Defense Academy, 1-10-20 Hashirimizu Yokosuka 239-8686)

*2 防衛大学校機能材料工学科 (Department of Materials Science and Engineering, National Defence Academy) 


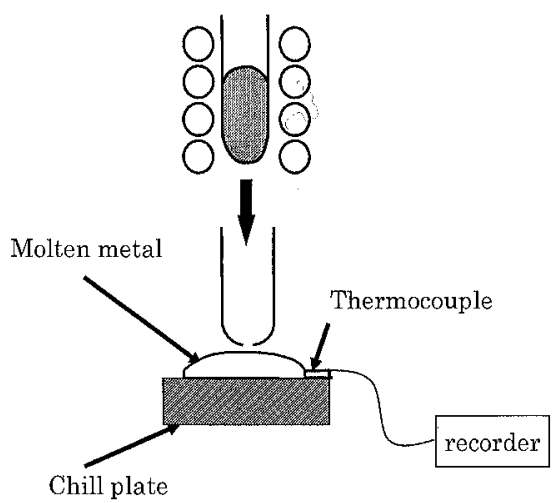

Fig. 1. A schematic drawing of the experimental apparatus.

Table 1. Chemical composition of the specimen for drop test $(\operatorname{mass} \%)$

\begin{tabular}{|c|c|c|c|c|c|c|c|c|}
\hline & $\mathrm{C}$ & $\mathrm{Si}$ & $\mathrm{Mn}$ & $\mathrm{P}$ & $\mathrm{S}$ & $\mathrm{Ni}$ & $\mathrm{Cr}$ & $\mathrm{Fe}$ \\
\hline SUS304 & 0.054 & 0.39 & 1.10 & 0.028 & 0.0045 & 8.05 & 18.14 & bal. \\
\hline S45C & 0.45 & 0.24 & 0.84 & 0.013 & 0.017 & 0.01 & 0.13 & bal. \\
\hline
\end{tabular}

設置した $\phi 0.1 \mathrm{~mm}$ の B 型熱電対を用いて, 熱電対の起電力 をサンプリング周期 $1 \mathrm{~ms}$ で収集，記録した。用いた鋼は 市販のSUS304とS45Cであり，それらの化学組成はTable 1 に示す。

\section{$2 \cdot 2$ 組織観察方法}

滴下した試料は直径約 $20 \mathrm{~mm}$ ，高さ約 $7 \mathrm{~mm}$ のボタン状 となる。它れを切断し，試料のチル板に接する面を試料 表面とし，試料表面に対して平行な面を $\mathrm{Z}$ 断面，垂直な面 をC断面とし，切断した試料の中心付近を観察した。得ら れた試料のミクロ組織の現出は，Z断面，C断面ともに耐 水研磨紙 (\#80 \#4000) で研磨し, バフ研磨後, SUS304 は 硝酸電解で，S45Cは塩化第二銅，界面活性剂を加えたピ クリン酸飽和液により腐食した。光学顕微鏡で凝固組織の 観察を行った。

\section{3. 実験結果}

\section{$3 \cdot 1$ 凝固組織観察}

Fig. 2 にSUS304 およびS45Cを $1550^{\circ} \mathrm{C} て ゙$ 溶解した試料の C断面の凝固組織示す。表面から内部に向けて成長した チル晶から柱状晶の領域であり，固液界面形態は共にデン ドライトである。S45Cのデンドライトは表面付近では不 明膫である。Fig. 2には示されていないが，両試料共に， 柱状晶は途中で成長が止まり，内部は等軸晶となっている。 デンドライトは一次枝と二次枝が確認でき, SUS304 と S45Cを比較すると, SUS304の二次枝の発達はより明瞭で あり，一次デンドライトアーム間隔はSUS304に比べて S45Cの方が大きい。SUS304の試料では，表面近くに水上 らが報告している二次枝のみられないセル状を呈する結晶
Mold side
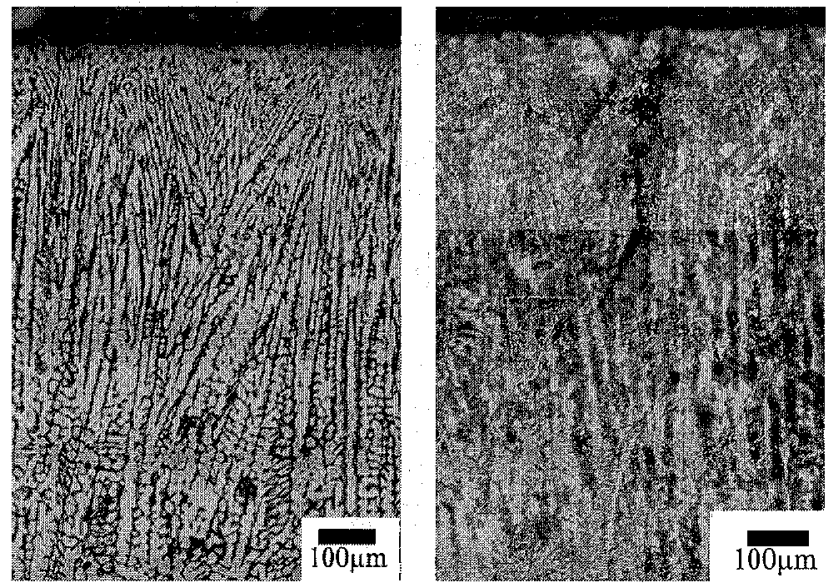

Fig. 2. Solidification structure of the specimen observed by an OM on the cross-section. (Left: SUS304 right: $\mathrm{S} 45 \mathrm{C}$ )

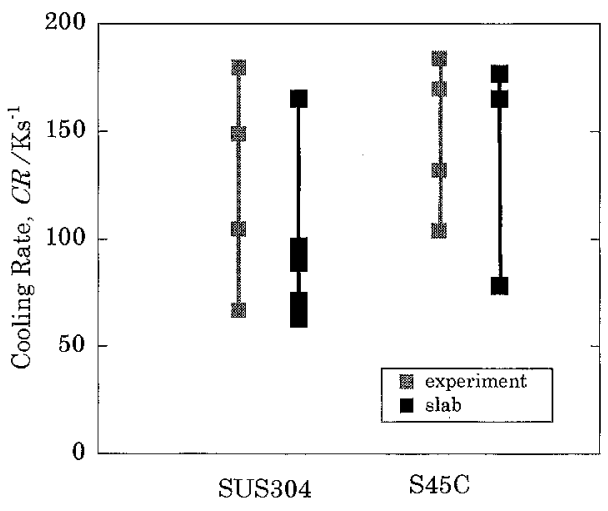

Fig. 3. Comparison between the cooling rate in drop test and that in the continuously cast products.

も存在して抢り，核生成時に十分過冷をしていたと思われ る。S45Cでは，本エッチング法により凝固組織と同時に， 凝固中から凝固後に変態で生じた $\gamma$ 相の粒界も観察でき る。

\section{$3 \cdot 2$ 冷却速度の評価}

滴下実験の試料と別途入手した一般的な操業で得られる 実鏻片の試料の冷却速度を，二次デンドライトアーム間隔 から見積もり ${ }^{10,11)}$ ，号の結果をFig. 3に示す。SUS304， $\mathrm{S} 45 \mathrm{C}$ ともに滴下実験の武料での泠却速度は実鋳片の冷却 速度とほぼ等しかった。

\section{$3 \cdot 3$ 凝固結晶粒の挙動}

Z断面，C断面いずれの面においても，同一の結晶方向 を有するデンドライトの群をひとつの粒とする。SUS304， $\mathrm{S} 45 \mathrm{C}$ を $1550^{\circ} \mathrm{C}$ で溶解, 滴下した試料の粒認識を行ない, 粒径を測定した。著者らはZ断面で㠜固組織を評価するこ とにより粒の挙動を明らかにすることを提案している が ${ }^{12)}$, 本研究に招いては，千ル板の接触面から数 $\mathrm{mm}$ 程度 の広い範囲にわたる粒の挙動を評価するためC断面で評価 を行った。Z断面で観察すると異なった粒もC断面での観 


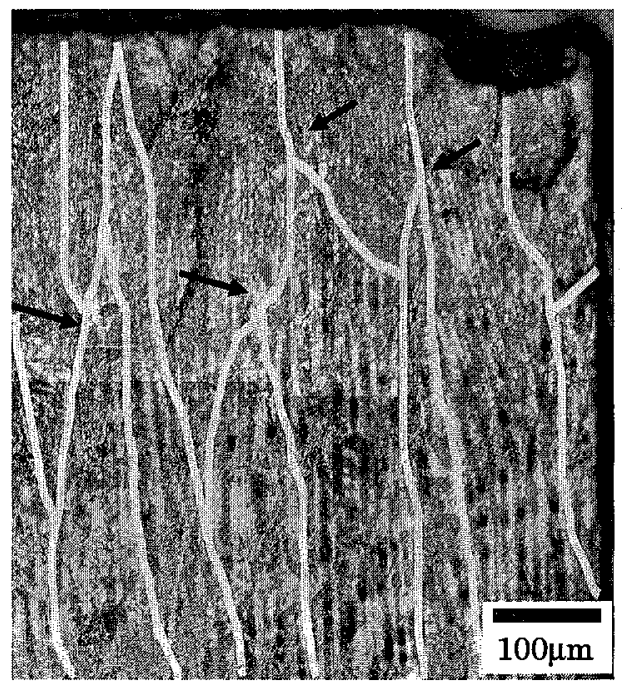

Fig. 4. Solidification structure of S45C and grain boundaries of the grain observed by an OM on the crosssection. The arrows indicate newly emerged grain across the observed plane.

察では同方向に成長していると評価する可能性も考无られ る。しかし，Z断面，C断面共に，鋳型付近では顕著な二 次枝の成長が見られずZ断面で測定する粒径も，C断面で 測定する粒径も近い値が得られたので，C断面評価でも定 量性に問題はないと判断した。

C断面における粒認識の一例を Fig. 4 に示す。粒は数本 のデンドライトで構成され，粒界は多少凹凸があるがほと んど直線に近い。そしていずれの粒も深さ方向に細長い。 また，途中から新たに粒が生成しているように観察される 部位もある (図中矢印)。これは観察面の前後から観察面 に斜めに入ってきた粒であると考えられる。

C断面上の粒径は切断法により決定した。すなわち，表 面からの所定の距離で水平の線分を引き，その線分長さを 切断した粒数で除することにより粒径を算出した。なお， 上述のと抢り，観察している部位では粒は深さ方向に長い 形状となるため, 本研究で求めた粒径は粒の幅に対応す る。

$1550^{\circ} \mathrm{C}$ で溶解したSUS304，S45Cについて，試料表面か らの距離と粒径の関係を Fig. 5に示す。C断面観察の結果, 約 $2 \mathrm{~mm}$ 内部に進むと柱状晶から等軸晶に遷移するため, 表面から約 $2 \mathrm{~mm}$ の範囲を観察領域とした。表面から $500 \mu \mathrm{m}$ 程度までは観察面の前後から斜めに入ってきた粒 があるために，粒径が減少する。最小值をとった後，どち らの鋼種についても粒径は多少の上下はあるものの大きく なっていく。鋼種を比較すると, SUS304は速やかに粒径 が増加するのに対し，S45C は表面から $1 \mathrm{~mm}$ 内部に入った ところであってもそれほど增加して打らず，粒径は緩やか にしか増加しない。

\section{4 初期凝固部のデンドライトの傾き分布}

Fig. 2に示したSUS304とS45CのC断面の凝固組織を比

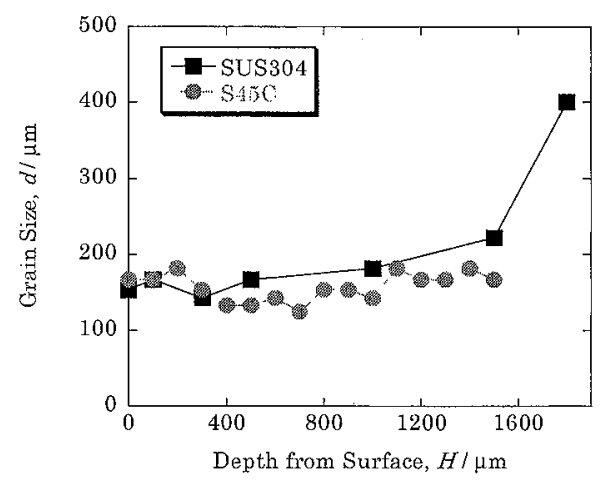

Fig. 5. Relation between depth from the surface and grain size.

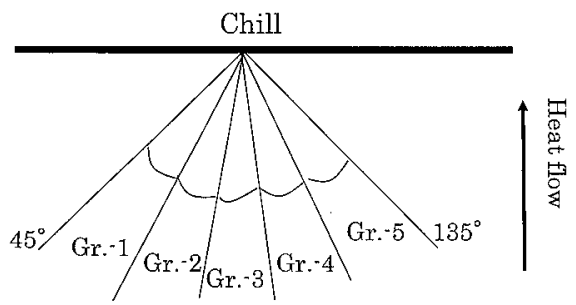

\begin{tabular}{cc}
\hline Gr. -1 & $45.0^{\circ} \sim 63.0^{\circ}$ \\
Gr. -2 & $63.0^{\circ} \sim 81.0^{\circ}$ \\
Gr. -3 & $81.0^{\circ} \sim 99.0^{\circ}$ \\
Gr. -4 & $99.0^{\circ} \sim 117.0^{\circ}$ \\
Gr. -5 & $117.0^{\circ} \sim 135.0^{\circ}$ \\
\hline
\end{tabular}

Fig. 6. Classification of deflection angles of dendrite trunks for histgram.

較すると，初期凝固部を構成するデンドライトの成長方向 に差があることがわかる。100本程度のデンドライトの成 長方向老測定寸ることにより，方位の分布を定量的に評価 した。S45Cにおいて表面付近ではデンドライトを明瞭に 顕出できないため，傾き分布測定は両鋼種ともに表面から $300 \mu \mathrm{m}$ 内部に入った，明瞭にデンドライトを確認できる 部分で行った。

両鋼種とも凝固時， $\delta$ 相がデンドライト凝固するが，兄

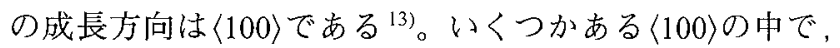
最も熱流方向に近い方向が主軸となる。すなわち，主軸の 方向は，表面から反時計回りに角度を測定した場合， $45^{\circ}$ から $135^{\circ}$ までの範囲をとりうると考えられる。この範囲 を Fig. 60 模式図に示すように $18^{\circ} こ ゙ と に 5$ 等分し，デンド ライトの傾き分布を測定した。 $y$ 軸は，全体のデンドライ トの本数に対する，その Gr.に分類されるデンドライトの 本数の割合として表示した。

この結果を Fig. 7に示す。いずれの鋼種についても Gr.-1 から Gr.-5に均一に分布しているわけではなく，Gr.-3の分 布は多く，Gr.-1 拉よびGr.-5の分布は少ない。Fig. 7の表示 方法に従えば，いずれの鋼種も山型分布であると言える。 SUS304ではGr.-1 とGr.-5の大きく傾いたデンドライトも 比較的多く存在するのに対し，S45Cはいずれも $1 \%$ 程度で ありほとんど存在しない。傾き角度が同じである，Gr.-2 


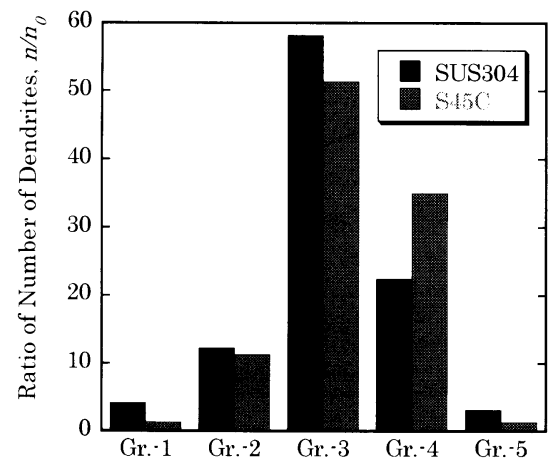

Fig. 7. Distribution of growth direction of dendrites.

と Gr.-4を比較すると, どちらの鋼種も Gr.-4が多い傾向が 認められる。これは，デンドライトは溶鋼流動の上流方向 に成長するために ${ }^{13)}$ ，滴下地点である試料中央部に向かっ てデンドライトが成長していたことを示している。

\section{4. 考察}

\section{$4 \cdot 1$ 粒選択モデルによる解析}

本研究で得られた粒の挙動について, これまで著者らが 開発した粒選択モデル(4-16)により検討を行った。

\section{$4 \cdot 1 \cdot 1$ 粒選択モデル}

粒選択モデルの詳細は別途報告しているので，ここでは 概要について説明する。初期状態である初期粒径と成長方 向を乱数で与え，隣接する粒がブランチングを起こすか， ブロッキングを起こすかを判断しながら粒選択挙動を予測 するモデルである。主に二次元での解析であり，初期条件 が決まればその後の成長がすべて決定する決定論的特徵を 有するモデルである。また，広い領域の粒選択挙動を短時 間に計算できるといった特徴を有する。一方，二次元にお ける解析であるのでFig. 4に示したような観察面への中途 出入や中途での核生成は考慮されていない。また，一般的 に実際の粒のサイズは合金組成，凝固条件により決定され るが，本モデルではサイズの予測はできない欠点がある。 しかし，粒の成長長さを初期粒径で，粒数を初期粒数でそ れぞれ規格化することにより，モデルと実験值の比較が可 能となると考えられる。なお，ここでは初期の粒数は 320 とし，粒径の逆数に比例する粒数を評価指標とした。

$4 \cdot 1 \cdot 2$ モデルの補正

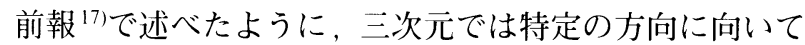
いないデンドライトを二次元で観察すると熱流方向に成長 したものが多いように観察できる。実際の測定值はFig. 7 に示した通り，Gr.-3に多くGr.-1，-5はそれに比べて少な い山型分布であり，前報の結果を支持している。

粒選択モデルの基本形は二次元で考えていたため，デン ドライトの成長方向の付与条件は $45^{\circ} \sim 135^{\circ}$ までの角度範 囲で均一としていた。しかし，このモデルは初期条件に関

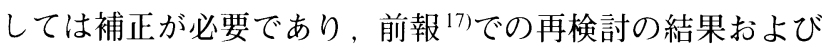

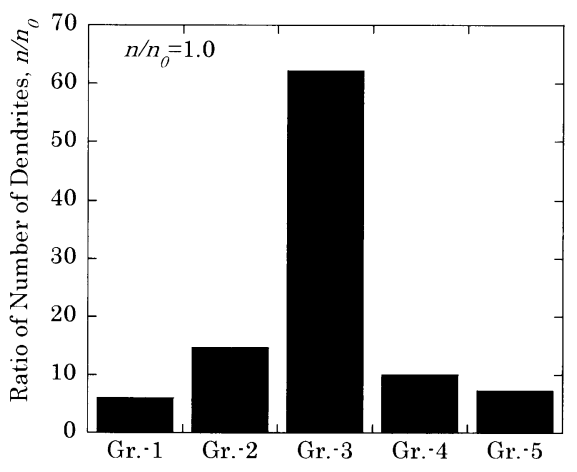

Fig. 8. Initial condition of distribution of growth direction of dendrites of the grain selection model for SUS304.

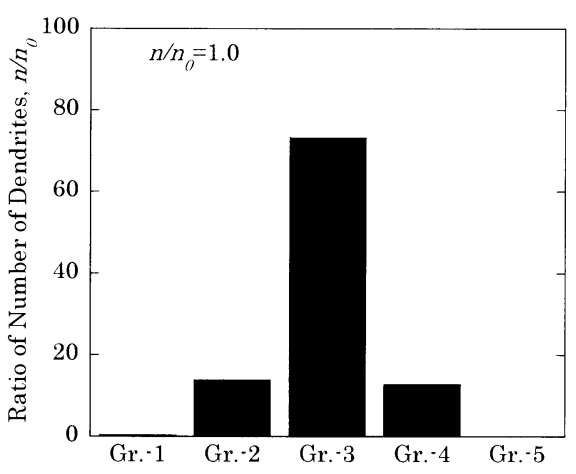

Fig. 9. Initial condition of distribution of growth direction of dendrites of the grain selection model for S45C.

Fig. 7に示した測定結果から, 三次元現象として起こって いる粒選択を二次元の観察面内で検討する場合には，初期 条件を $45^{\circ} \sim 135^{\circ}$ での角度範囲で均一分布と考えてはいけ ないことが明らかになった。すなわち，Fig.7に示したよ うな山型分布になるように初期条件を与える必要がある。 また，いずれの鋼種も山型分布であるが前述の通り SUS304とS45Cでは差が見られたので試行錯䛊により初期 条件に合致するように次のように調整した。SUS304に関 しては, 角度範囲は基本形通り 45から $135^{\circ}$ のまました。 初期に与える乱数の分布を変化させ，傾き角度をGr.-3の 分布が多い山型分布となるように補正した。また $445 \mathrm{C}$ は Gr.-1，Gr.-5に分類されるデンドライトがほとんどないの で, 山型分布でなおかつ角度範囲 Gr.-2, -3，-4のみに分布

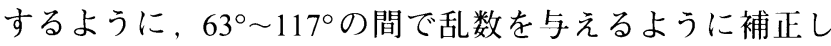
た。補正方法の可否を確かめるためにSUS304 およびS45C について補正後の初期条件としてのデンドライトの傾き分 布をそれぞれFig. 8，Fig. 9に示す。Fig. 8，9の結果と Fig. 7の SUS304，S45Cの傾き分布は溶鋼の流動を考慮すると おおむね一致する。

$4 \cdot 1 \cdot 3$ モデルと実験值の比較

SUS304, S45Cの粒数の変化について, 実験值と補正前 の基本モデルでの計算結果とを比較したものをそれぞれ，

Fig.10, 11 に示す。 


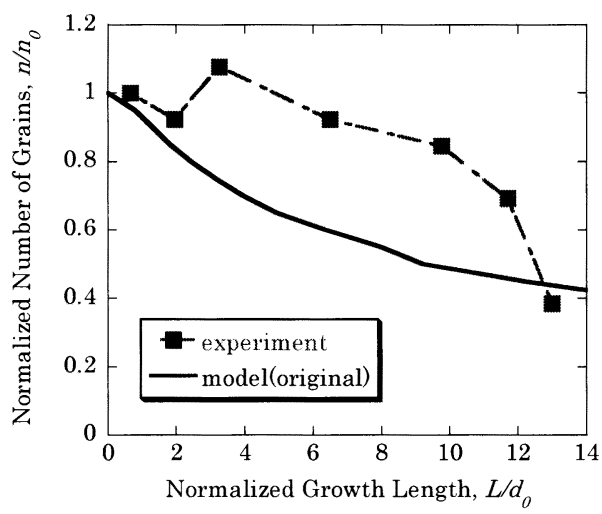

Fig. 10. Comparison between experiment and original model for number of grains obtained in SUS304.

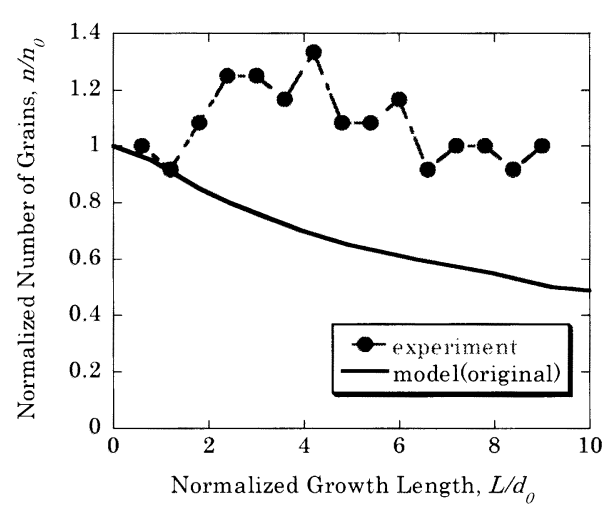

Fig. 11. Comparison between experiment and original model for number of grains obtained in S45C.

実験值は $3 \cdot 3 て ゙$ 述べたように観察面の前後から観察面に 粒が入ってくるために一旦粒数は増加するがその後減少し ている。モデルの計算結果は粒の流入などは考虑していな いので成長距離と共に一様に減少する。いずれも成長距離 の增加につれて粒数が減少する点で一致している。Fig.10 に示したSUS304の場合, 一旦増加した後の実験値の減少 の様子とモデル計算結果はほぼ一致していると言えるが， モデルの方がやや勾配が大きいようである。一方，Fig.11 に示したS45Cの場合, 実験值の減少の様子とモデル計算 結果は一致せず，モデルの勾配の方が大きい。これはモデ ルで予想するよりも実際におこった粒選択の頻度が低かっ たことを示している。

次に初期凝固部のデンドライトの成長方向分布を補正後 の Fig. 8 (SUS304)，Fig. 9 (S45C)のように与えた場合の， モデル計算結果と実験結果との比較を Fig.12，13に示す。 なお，これらにはFig.10，11の補正前のモデル計算結果を 破線で示す。Fig.12に示したSUS304のモデル計算結果で は，Fig.10でのモデル計算結果よりも勾配が緩やかになっ ており，実験值の勾配により近くなっていると判断できる。 Fig.13のS45Cの場合, 補正後の勾配はFig.11よりも緩やか になっており実験值の減少の様子に極めて近い。これは, 熱流方向に近いGr-3に成長するデンドライトが多くなり，

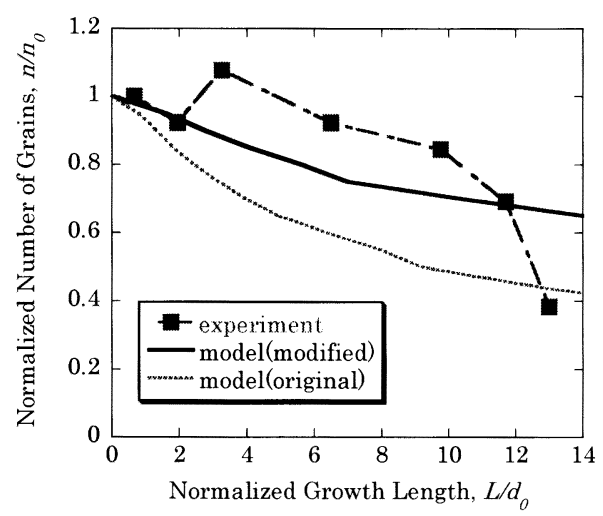

Fig. 12. Comparison between experiment and modified model for number of grains obtained in SUS304.

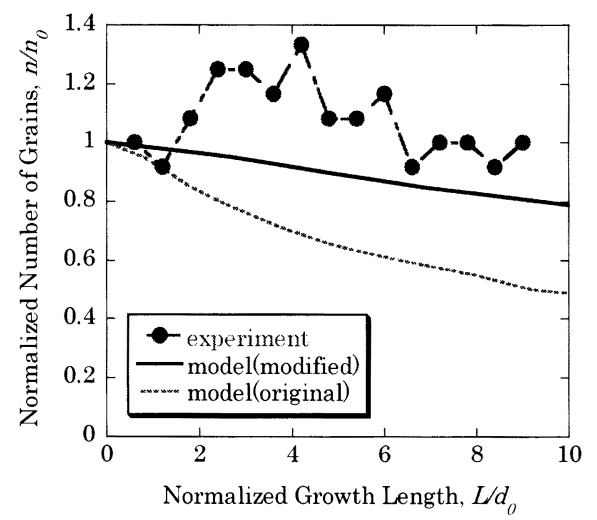

Fig. 13. Comparison between experiment and modified model for number of grains obtained in S45C.

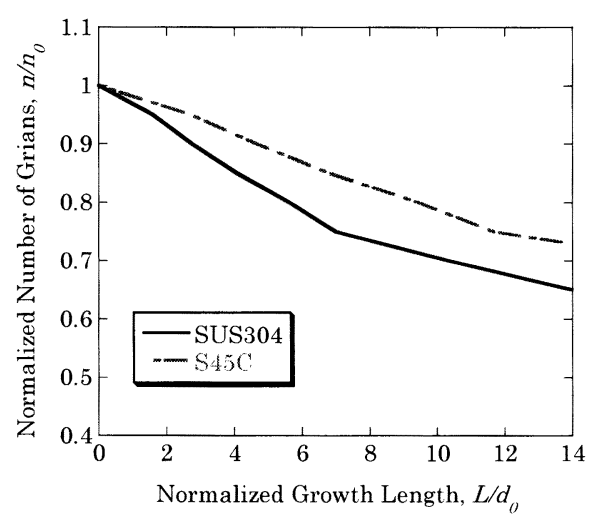

Fig. 14. Comparison between number of grains in SUS304 and that in $\mathrm{S} 45 \mathrm{C}$ obtained by the grain selection model.

ブロッキングが生じにくく，粒選択が起こりにくくなるた めである。

ここで, SUS304 とS45Cの粒数の挙動を比較するために， 粒選択モデル計算結果を 1 つの図にまとめたものを Fig. 14 に示す。SUS304は成長距離と共に粒数が速やかに減少す るのに対し，S45Cはゆるやかにしか減少しないことが明 らかである。この差はデンドライトの傾き分布の違いによ る。すなわち，SUS304は大きく傾いて成長するデンドラ イトが多いために，ブロッキングが頻繁におこり，粒数が 
すぐに減少する。一方，S45Cは熱流方向であるGr.-3に分 類されるデンドライトが多くなるために，ブロッキングは 生じにくく，粒選択が起こらず，粒数は緩やかにしか減少 しない。以上のことより，デンドライトの傾き分布が，粒 径の大きさ変化挙動に大きな影響を与えることが明らかと なった。

なお，本研究では初期凝固部のデンドライトの傾き分布 測定は表面から $300 \mu \mathrm{m}$ の位置で行っており，この間の粒 選択も考元られるが，Fig. 5からわかるようにSUS304も S45Cも表面近くにおいては，粒径はそれほど変化しない ので, $300 \mu \mathrm{m}$ までの粒選択の影響はないと判断できる。

\section{$4 \cdot 2$ 初期凝固部のデンドライトの傾き分布に及ぼす溶解 温度の影響}

Fig. 2 をみると，表面付近でSUS304 と S45Cのデンドラ イトの成長の様子が異なることがわかる。SUS304はある 点を起点に放射状にデンドライトが成長しており，S45C はほぼ熱流方向に成長している。また表面から $300 \mu \mathrm{m} の$ 位置のデンドライトの傾き分布はFig. 6に示したように鋼 種により大きく異なる。SUS304 とS45Cでは，固液界面工 ネルギー，液相線温度などの物性值が異なるため形成され る凝固組織が異なることが予想される。しかし本研究では， そのうちのSUS304 とS45Cの液相線温度の差に着目した。 SUS304 の液相線温度 $\left.{ }^{18}\right)$ は $1460^{\circ} \mathrm{C}, \mathrm{S} 45 \mathrm{C}$ の液相線温度 ${ }^{19}$ は $1494^{\circ} \mathrm{C}$ と $34^{\circ} \mathrm{C}$ 異なる。一方, 溶解温度は一定として実験 しているため、スーパーヒート $(\Delta T S)$ が異なる。したがっ て, $\Delta T s$ 差がデンドライトの傾き分布の違いに寄与して いるのではないかと考え，溶解温度を変化した実験を行っ た。

高周波誘導加熱により，液相線温度よりやや高めの $1500^{\circ} \mathrm{C}$ 以上の実験可能な温度に溶解温度を変化させた。 SUS304では溶融金属の表面張力が小さくなること，粘度 が小さくなること，溶解中の流動が激しくなること等の理 由により，溶解途中に石英管の小孔から溶融金属が漏れて しまうため, $1600^{\circ} \mathrm{C}$ が本実験装置の最大溶解温度であっ

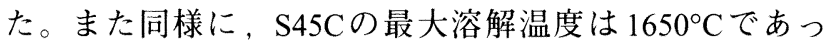
た。

SUS304，S45Cそれぞれについて，溶解温度を変化させ 作成した試料の，表面から $300 \mu \mathrm{m}$ のころのデンドライ トの傾きを調査した結果をそれぞれFig.15，Fig.16に示す。 いずれの鋼種，溶解温度でも Gr.-3に分類されるデンドラ イトが多く，Gr.-1，Gr.-5に分類されるデンドライトが少 ない山型分布であることは共通している。しかし溶解温度 が高くなるにつれて，Gr-1，Gr.-5に分類されるデンドラ イトが増加することがわかる。SUS304を $1600^{\circ} \mathrm{C} て ゙$ 溶解す ると， $\Delta T s$ は $140^{\circ} \mathrm{C}, S 45 \mathrm{C}$ を $1650^{\circ} \mathrm{C}$ で溶解すると $\Delta T s$ は $156^{\circ} \mathrm{C}$ である。また, SUS304を $1500^{\circ} \mathrm{C}$ で溶解すると $\Delta T S$ は $40^{\circ} \mathrm{C} ， \mathrm{~S} 45 \mathrm{C}$ を $1550^{\circ} \mathrm{C}$ で溶解すると $\Delta T s$ は $56^{\circ} \mathrm{C}$ である。 $50^{\circ} \mathrm{C}$ と $150^{\circ} \mathrm{C}$ と同じ $\Delta T S$ での実験結果を SUS 304 と S45Cに

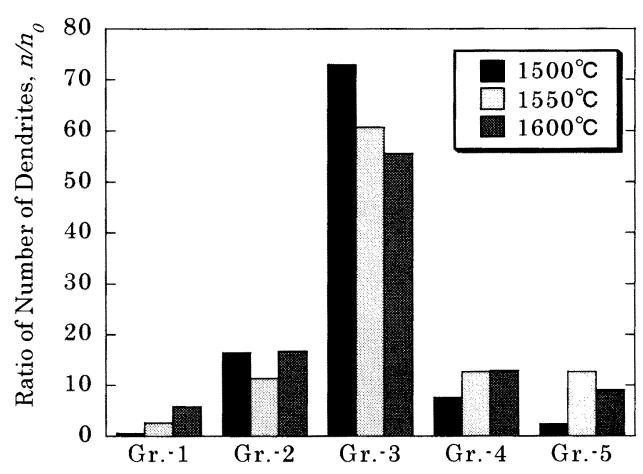

Fig. 15. Distribution of growth direction of dendrites as a function of melting temperature obtained in SUS304.

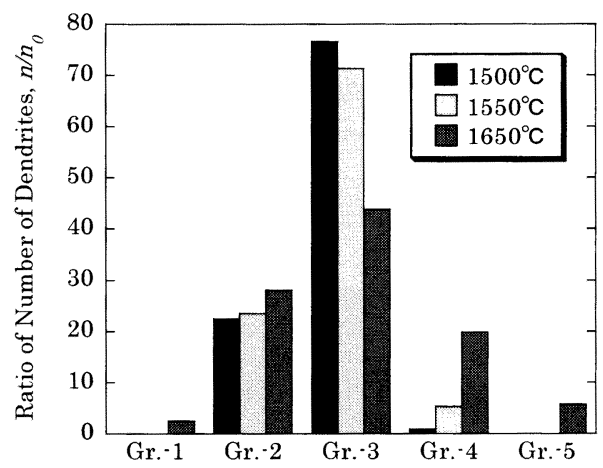

Fig. 16. Distribution of growth direction of dendrites as a function of melting temperature obtained in S45C.

ついて比較し，Fig.17およびFig.18に示す。 $50^{\circ} \mathrm{C}$ のとき(Fig.17)は，いずれの鋼種についても Gr.-3に多 く分布し，Gr.-1 およびGr.-5に分類されるデンドライトは 極めて少ない。それに対し， $\Delta T S$ が $150^{\circ} \mathrm{C}$ と大きくなると Gr.-3の分布はやや減少し，大きく傾いたGr.-1 や Gr.-5に分 布が広がる傾向が認められる。同じ $\Delta T s て ゙$ 比較すると，両 鋼種のデンドライトの傾き分布の傾向が等しくなる。

このことから，デンドライトの傾き分布は $\Delta T s に$ に依存し， $\Delta T s$ が大きいほど大きく傾くデンドライトの割合が高くな ることがわかった。この理由は次のように推定できる。溶 解温度が低温で $\Delta T S$ が小さりとき，千ル板近傍での核生成 が容易になり，デンドライトが熱流方向と平行に成長でき る。一方, 溶解温度が高温で $\Delta T S$ が大きいとき, 核生成頻 度は小さくなるため, 核生成する前にチ儿板近傍の融液が 大きく過冷する。そこで核生成すると，広く大きく過冷し ていた液相中をデンドライトは放射状に急速に成長でき る。そのためにデンドライトの傾き分布が広くなる。 $\Delta T S$ を大きくすると，核生成にある程度有効な溶融金属内の酸 化物または窒化物が，高温で鋼を溶解する間に溶解してし まい，それらの持つ鋼の核生成能が消失してしまう。低温 溶解であれば，それらの異質核は残存でき，核生成能を有 したまま凝固が始まる。チル板表面での初期凝固の状況が 変化するのはこのように推測できる。ただし，今回の研究 の範囲では核生成に寄与した物質は同定できず，チル板近 


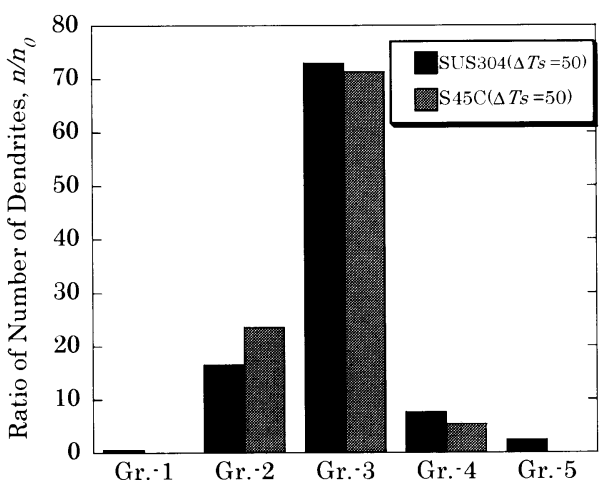

Fig. 17. Distribution of growth direction of dendrites obtained in SUS304 and S45C at about the same superheat $\left(\fallingdotseq 50^{\circ} \mathrm{C}\right)$.

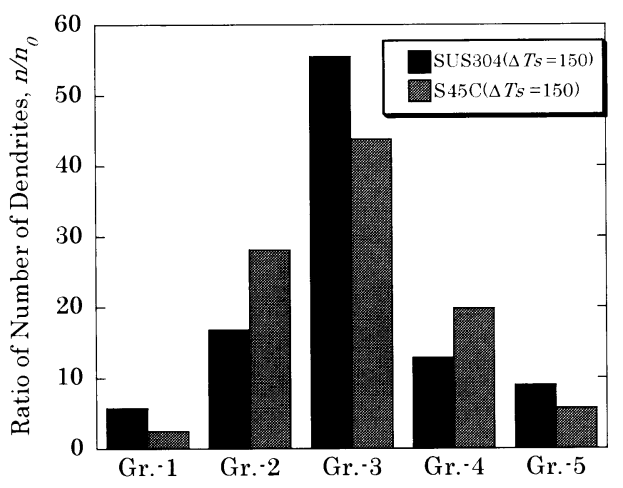

Fig. 18. Distribution of growth direction of dendrites obtained in SUS304 and S45C at about the same superheat $\left(\fallingdotseq 150^{\circ} \mathrm{C}\right)$.

傍で作用する異質核についての解析は今後の課題である。

また，筆者らは中炭素鋼において，チル板表面粗度の変 化による組織形成を検討した ${ }^{20)}$ 。鋳型近傍で $20^{\circ} \mathrm{C}$ 過冷し た場合に, 凝固組織を顕出しにくい半球状の組織となるこ とを見出している。今回の実験では過冷度の測温を行って いないので㛜密な比較はできないが， $\Delta T s$ が大きい場合， いずれの鋼種でもデンドライトが放射状に成長している が, 半球状の微細な組織とまではなっていない。したがっ

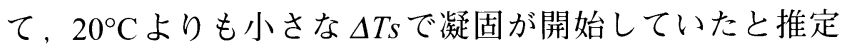
される。

以上のことから， $\Delta T S$ がチル板表面での核生成に影響し， 核生成時の過冷度が初期凝固のデンドライト成長の微細化 や傾き分布に影響を与えていることがわかる。

\section{5. 結言}

連続鋳造プロセスの初期凝固現象の理解の解明のため
に，現行の連続鋳造と同等である冷却条件でSUS304 およ びS45Cを滴下凝固させ，粒選択挙動を検討した結果，以 下の点が明らかになった。

(1) $1550^{\circ} \mathrm{C}$ の溶解温度では, 滴下すると凝固の進行と 共にSUS304 は粒径が速やかに増大するのに対し，S45Cは 緩やかにしか増大しない。これはデンドライトの成長方向 の角度範囲に依存する。

（2）合金による粒選択挙動の差は，デンドライト成長 方向の分布を初期条件と一致するように改良した粒選択モ デルを用いて定量的に説明できる。

（3）初期凝固時のデンドライトの成長方向分布は, 過 熱度 $(\Delta T s)$ に依存し， $\Delta T s$ が大きいと大きく傾いたデンド ライトが増加する。これは， $\Delta T s$ が大きい場合には異質核 として作用する物質が消滅するためであると推定される。

\section{文献}

1 ) T.F.Bower and M.C.Flemings: Trans. Metall. Soc. AIME, 239 (1967), 1620.

2 ) H.Biloni and B.Chalmers: Trans. Metall. Soc. AIME, 233 (1965), 373.

3 ) H.Biloni and B.Chalmers: Trans. Metall. Soc. AIME, 236 (1966), 930.

4 ) N.Nishi, H.Takeuchi and S.Uchida: Proc. School Eng. Tokai Univ. 24 (1984), 97.

5 ) N.Nishi, H.Takeuchi and S.Uchida: Imono, 54 (1982), 11, 718.

6 ) H.Mizukami, T.Suzuki and T.Umeda: Tetsu-to-Hagané, 77 (1991), 1672.

$7)$ H.Mizukami, T.Suzuki and T.Umeda: Tetsu-to-Hagané, 78 (1992), 580

$8)$ H.Mizukami, T.Suzuki and T.Umeda: Tetsu-to-Hagané, 78 (1992), 767.

9 ) H.Mizukami, T.Suzuki and T.Umeda: Tetsu-to-Hagané, 78 (1992), 1369.

10) A.Suzuki, T.Suzuki, Y.Nagaoka and Y.Iwata: J. Jpn. Inst. Met., 32 (1968), 1301.

11) H.Esaka, S.Mizoguchi, H.Kajioka and H.Chida: CAMP-ISIJ, 1 (1988), 268

12) W.Kurz and D.J.Fisher: Fundamentals of solidification, Trans Tech Publications, Aedermannsdorf, Switzerland, (1984), 64.

13) T.Takahashi, K.Ichikawa, M.Kudou and K.Shimahara: Tetsu-toHagané, 61 (1975), 2198.

14) H.Esaka, K.Fujita, H.Daimon, M.Tamura and K.Shinozuka: J. Jpn. Inst. Met., 64 (2000), 1206

15) H.Esaka, K.Shinozuka and M.Tamura: ISIJ Int., 43 (2003), 1751.

16) H.Esaka, K.Shinozuka and M.Tamura: Mater. Trans., 44 (2003), 829

17) H.Esaka, Y.Kuroda, K.Shinozuka and M.Tamura: Tetsu-to-Hagané, 92 (2006), 427.

18) A.Kagawa and T.Okamoto: Mater. Sci. Technol., 2 (1986), 997.

19) 川和高穂：私信 (1973)

20) H.Esaka, T.Shirakami, T.Mizoguchi and S.Ogibayashi: Tetsu-toHagané, 81 (1995), 631. 